\title{
Perbandingan Hasil Belajar Mahasiswa Prodi Pendidikan Bahasa Jepang dan Sastra Cina Angkatan 2015 Universitas Brawijaya
}

\author{
ULFAH SUTIYARTI $* 1$, DIAH AYU WULAN ${ }^{2}$, FEBI ARIANI \\ SARAGIH $^{3}$, GALIH EDY NUR WIDYANINGSIH ${ }^{4}$ \\ 'Program Studi Pendidikan Bahasa Jepang, Program Studi Bahasa Cina Universi- \\ tas Brawijaya \\ ulfahsutiyarti@yahoo.com \\ diahayuwulan96@yahoo.co.id \\ emiwk74@yahoo.co.jp \\ jiali.gw@gmail.com
}

\begin{abstract}
ABSTRAK
Penelitian ini bertujuan untuk mengetahui perbedaan perolehan hasil belajar mahasiswa PS Pendidikan Bahasa Jepang dan PS Sastra Cina angkatan 2015 dalam IPK berdasarkan jenis seleksi masuk perguruan tinggi. Penelitian berjenis ex post facto (meneliti keadaan yang sudah terjadi), maka pada penelitian ini hanya melihat hasil belajar siswa dari cara masuk perguruan tinggi, dan tidak melihat proses belajar masing-masing program studi. Hasil penelitian diharapkan dapat menjadi pertimbangan dalam menentukan kuota jalur seleksi masuk mahasiswa. Penelitian ini merupakan penelitian deskriptif kuntitatif dengan subyek penelitian mahasiswa PS Pendidikan Bahasa Jepang dan PS Sastra Cina angkatan 2015. Teknik pengumpulan data mengunakan teknik dokumentasi yaitu KHS mahasiswa. Analisis data dilakukan dengan :1) Uji asumsi menggunakan uji normalitas data dan uji homogenitas, 2) analisis ragam One-way ANOVA. Hasil penelitian menunjukkan PS Sastra Cina prestasi belajar mahasiswa jalur mandiri memiliki IPK yang tidak berbeda jauh dengan jalur SNMPTN dan SBMPTN sedangkan pada PS Pendidikan Jepang, mahasiswa yang dari jalur mandiri berada dibawah SBMPTN mengalahkan nilai IPK mahasiswa jalur SNMPTN. Sehingga dapat disimpulkan bahwa jalur masuk perguruan tinggi masih belum dapat menjamin prestasi belajar mahasiswa di perguruan tinggi. Minat dan perhatian akan menghasilkan motivasi belajar dan keinginan berhasil dalam diri mahasiswa merupakan modal utama untuk meraih prestasi setinggi-tingginya di perguruan tinggi Kata Kunci: hasil belajar, jalur masuk SPMB
\end{abstract}

\footnotetext{
ABSTRACT

This study aims to determine differences in the acquisition of learning outcomes of students of Japanese Language Education and Chinese Literature Class of 2015 in GPA based on the type of college entrance selection. This research used ex post facto type (examine the circumstances that have happened), and also this study only see student learning
} 
outcomes from college entrance, and do not see the learning process of each study program. The results of the study are expected to be considered in determining the quota of student admission selection path. This research is a quantitative descriptive study with research subjects of students of Japanese Language Education and Chinese Literature Class of force of 2015. Data collection technique using documentation technique is KHS student. Data analysis was performed by: 1) Assumption test using data normality test and homogeneity test, 2) One way ANOVA analysis. The results of the study show that the Chinese Literature Study achievement of independent students has a GPA not much different from the SNMPTN and SBMPTN lines. Meanwhile, in the Japanese Education Education Program, students from independent pathways under SBMPTN defeat students' IPK score of SNMPTN. So it can be concluded that college entrance is still not able to guarantee student achievement in college. Interest and attention will result in learning motivation and successful desire in students is the main capital to achieve the highest achievement in collegesuccessful desire in students is the main capital to achieve the highest achievement in college

Keywords: learning outcomes, students admission.

\section{PENDAHULUAN}

Dalam usaha untuk mempersiapkan lulusan yang berkualitas, sebuah Perguruan Tinggi bisa melakukan salah satunya adalah dengan perubahan dan perbaikan pada kegiatan seleksi masuk mahasiswa. Kegiatan seleksi masuk mahasiswa dimaksudkan untuk memperluas akses pendidikan bagi semua kalangan masyarakat Indonesia tanpa membedakan ras, jenis kelamin, suku kedudukan sosial maupun tingkat kemampuan ekonomi. Seleksi masuk mahasiswa di Perguruan Tinggi Negeri menurut Peraturan Menteri Riset, Teknologi, dan Pendidikan Tinggi Nomor 2 Tahun 2015 tentang Penerimaan Mahasiswa Baru Program Sarjana pada Perguruan Tinggi Negeri terdapat 3 macam jenis. Pertama, jalur Seleksi Nasional Masuk Perguruan Tinggi Negeri (SNMPTN). Kedua, Seleksi Bersama Masuk Perguruan Tinggi Negeri (SBMPTN), dan jalur Mandiri.

Program Studi Pendidikan Bahasa Jepang dan Program Studi Sastra Cina merupakan salah satu Program Studi yang menerima mahasiswa yang masuk melalui SNMPTN, SBMPTN dan Ujian Mandiri Universitas Brawijaya. Hasil belajar mahasiwa Prodi Pendidikan Bahasa Jepang dan Prodi Sastra Cina yang masuk melalui ketiga jalur tersebut bervariasi. Hasil belajar ini akan berpengaruh terhadap lama studi mahasiswa. Tinggi rendahnya hasil belajar mencerminkan kualitas pendidikan. Kualitas 
pendidikan yang baik dapat dicapai dengan cara menerapkan proses belajar yang efektif dan efisien. Hasil belajar merupakan bagian akhir dari proses belajar.

Salah satu bentuk hasil belajar mahasiswa ditunjukkan dengan IPK (Indeks Prestasi Kumulatif yang diketahui pada setiap semester. Penelitian ini bertujuan untuk mengetahui tentang perbedaan perolehan hasil belajar mahasiswa yang dinyatakan dengan IPK (Indeks Prestasi Kumulatif) berdasarkan jenis seleksi masuk perguruan tinggi jalur SNMPTN, SBMPTN dan jalur Mandiri. Tentu saja hasil belajar akan dipengaruhi banyak hal, namun dalam penelitian ini hanya dibatasi dari cara masuk universitas. Diharapkan hasil penelitian ini dapat menjadi pertimbangan untuk menentukan besaran kuota jalur masuk penerimaan Universitas Brawijaya serta memberikan sumbangan dalam upaya meningkatkan pembinaan mahasiswa Program Studi Pendidikan Bahasa Jepang dan Program Studi Sastra Cina sehingga dapat menghasilkan lulusan yang berkompeten.

Penerimaan mahasiswa baru harus memenuhi prinsip adil, akuntabel, transparan, dan tidak diskriminatif dengan tidak membedakan jenis kelamin, agama, suku, ras, kedudukan sosial, dan tingkat kemampuan ekonomi calon mahasiswa serta tetap memperhatikan potensi calon mahasiswa dan kekhususan perguruan tinggi. Perguruan tinggi sebagai penyelenggara pendidikan setelah pendidikan menengah menerima calon mahasiswa yang berprestasi akademik tinggi dan diprediksi akan berhasil menyelesaikan studi di perguruan tinggi berdasarkan prestasi akademik. Jalur masuk Perguruan Tinggi Negeri terbagi dalam 3 (tiga) jalur yaitu SNMPTN (Seleksi Nasional Masuk Perguruan Tinggi Negeri), SBMPTN (Seleksi Bersama Masuk Perguruan Tinggi Negeri) dan Mandiri.

SNMPTN merupakan pola seleksi nasional berdasarkan hasil penelusuran prestasi akademik dengan menggunakan rapor semester 1 (satu) sampai dengan semester 5 (lima) bagi SMA/SMK/ MA atau sederajat dengan masa belajar 3 (tiga) tahun atau semester 1 (satu) sampai dengan semester 7 (tujuh) bagi SMK 
dengan masa belajar 4 (empat) tahun, serta portofolio akademik. Siswa yang berprestasi tinggi dan konsisten menunjukkan prestasinya layak mendapatkan kesempatan untuk menjadi calon mahasiswa melalui SNMPTN.

Jalur yang kedua adalah seleksi tertulis yang bernama Seleksi Bersama Masuk Perguruan Tinggi (SBMPTN) SBMPTN sebelumnya bernama SNMPTN tulis, selanjutnya digunakan istilah SBMPTN untuk seleksi masuk ke perguruan tinggi melalui jalur tes tulis. Seleksi melalui jalur tersebut didasarkan pada pertimbangan hasil tes tertulis secara langsung. Tes dilaksanakan dengan menggunkan alat seleksi berupa perangkat soal yang harus dikerjakan oleh calon mahasiswa baru selaku peserta tes. Adapun kuota mahasiswa baru yang akan diterima melalui jalur SBMPTN paling sedikit $30 \%$.

Sedangkan untuk jalur Seleksi Mandiri, dilaksanakan sendiri oleh masing-masing PTN setelah pengumuman SBMPTN. Seleksi Mandiri oleh masing-masing PTN salah satunya dengan menggunakan atau memanfaatkan nilai hasil tes SBMPTN yang difasilitasi oleh Panitia Pusat. Adapun kuota mahasiswa baru yang akan diterima melalui jalur Seleksi Mandiri paling banyak $20 \%$.

Terdapat empat alasan utama mengapa perguruan tinggi menyelenggarakan seleksi dalam penerimaan calon mahasiswa baru, yaitu 1) Pendidikan di perguruan tinggi merupakan ajang penyiapan calon pemimpin bangsa di masa yang akan datang, karena itu diperlukan suatu "kepastian" bahwa para calon mahasiswa yang akan belajar di perguruan tinggi memiliki kualitas yang baik, 2) Kesempatan untuk belajar di perguruan tinggi merupakan kesempatan yang langka terutama di negara yang sedang berkembang seperti di Indonesia, sehingga perguruan tinggi mengharapkan peluang yang langka tersebut diberikan kepada calon yang paling potensial dan paling berhak mendapatkannya. 3) Adanya seleksi memungkinkan untuk terjaringnya calon-calon mahasiswa bertalenta tinggi. 4) Kesempatan pendidikan tinggi merupakan suatu hal yang sangat 
mahal, sehingga harus dimanfaatkan secara efektif dan efisien oleh para calon mahasiswa yang paling besar kemungkinannya untuk berhasil dalam belajar di masa yang akan datang. Suryabrata (2005) .

Berdasarkan alasan tersebut di atas maka diperlukan suatu sistem yang ideal dan berkualitas untuk penerimaan calon mahasiswa baru di perguruan tinggi, sehingga anak didik yang memperoleh kesempatan belajar di perguruan tinggi merupakan putra-putri bangsa yang potensial dan yang berhak mendapatkannya.

Nur Ghufron \& Rini Risnawati (2012:9) mengemukakan bahwa prestasi belajar adalah hasil akhir dari aktivitas belajar siswa atau mahasiswa yang dinyatakan dalam bentuk huruf dan angka. Chomadi (dalam Herman Hidayat \& Karsono Suratno: 2010:13) menyatakan bahwa prestasi belajar merupakan hasil yang dicapai selama mengikuti pelajaran pada periode tertentu dalam suatu lembaga pendidikan dimana hasil dinyatakan dengan melalui penilaian, yang dapat diwujudkan dalam angka atau simbol.

Salah satu indikator untuk mengukur keberhasilan mahasiswa dalam menguasai kompetensi pembelajaran adalah prestasi belajar. Prestasi belajar diperoleh mahasiswa setelah mengikuti kegiatan perkuliahan yang diwujudkan dalam skor atau angka yang tercermin pada Indeks Prestasi Komulatif atau yang biasa disebut dengan IPK. Dalam setiap semester disajikan sejumlah matakuliah dan setiap matakuliah mempunyai bobot yang dinyatakan dalam satuan kredit semester (sks). Satuan Kredit Semester (yang selanjutnya disingkat SKS) adalah Satuan Kredit Semester (sks) merupakan satuan yang digunakan untuk menyatakan besar beban studi mahasiswa dalam suatu semester dan besarnya pengakuan atas keberhasilan usaha mahasiswa, serta besarnya usaha penyelenggaraan program pendidikan di perguruan tinggi. Dalam kegiatan pembelajaran, indikator keberhasilan mahasiswa dalam studi dapat dilihat dari nilai-nilai perolehan mahasiswa dalam Kartu Hasil Studi (KHS). 
Berdasarkan buku pedoman akademik Fakultas Ilmu Budaya Universitas Brawijaya

TABEL 1: HASIL PENILAIAN AKHIR MATAKULIAH

\begin{tabular}{|c|c|c|c|}
\hline \multirow{2}{*}{$\begin{array}{l}\text { HURUF } \\
\text { MUTU }\end{array}$} & \multicolumn{3}{|c|}{ GOLONGAN KEMAMPUAN } \\
\hline & MUTU & & ANGKA \\
\hline A & 4 & Sangat Baik & $81-100$ \\
\hline$B+$ & 3,5 & $\begin{array}{l}\text { Antara Sangat Baik dan } \\
\text { Baik }\end{array}$ & $76-80$ \\
\hline B & 3 & Baik & $70-75$ \\
\hline $\mathrm{C}+$ & 2,5 & Antara Baik dan Cukup & $61-69$ \\
\hline $\mathrm{C}$ & 2 & Cukup & $56-60$ \\
\hline D+ & 1,5 & Antara Cukup dan Kurang & $51-55$ \\
\hline D & 1 & Kurang & $45-50$ \\
\hline E & 0 & Gagal & $0-44$ \\
\hline
\end{tabular}

Pemberian nilai pada setiap kegiatan dapat dilakukan dengan huruf mutu (E-A) yang kemudian dikonversikan ke Angka Mutu (0-4) Penghitungan nilai akhir dilakukan dengan memberikan bobot pada setiap kegiatan perkuliahan dalam semester tersebut dengan rincian sebagai berikut.

Kuis (K): 15\% , Tugas terstruktur (TS) : 20\%, Praktikum (P): 10\%, Ujian tengah semester (UTS): $25 \%$, Ujian akhir semester (UAS): $30 \%$. Penyesuaian terhadap rincian penilaian di atas dapat dilakukan sesuai karakteristik matakuliah tersebut.

Dalam Kamus Besar Bahasa Indonesia, prestasi belajar adalah penguasaan pengetahuan atau keterampilan yang dikembangkan oleh mata pelajaran, lazimnya ditunjukkan dengan nilai tes atau angka nilai yang diberikan oleh guru. Menurut Benyamin S. Bloom, prestasi belajar merupakan hasil perubahan perilaku yang meliputi 3 (tiga) ranah kognitif terdiri atas pengetahuan, aplikasi, analisis, sintesis, dan evaluasi. Hamalik (2001) berpendapat prestasi belajar adalah perubahan sikap dan tingkah laku setelah menerima pelajaran atau setelah mempelajari sesuatu.

Menurut Syaiful Bahri Djamarah, (1994:94) prestasi adalah hasil dari suatu kegiatan yang telah dikerjakan, diciptakan baik secara individu maupun secara kelompok. Sedangkan Mas'ud 
Hasan Abdul Dahar (dalam Syaiful Bahri Djamarah, 1994:19) menyatakan bahwa prestasi adalah apa yang telah dapat diciptakan, hasil pekerjaan, hasil yang menyenangkan hati yang diperoleh dengan jalan keuletan kerja.

Untuk memeroleh prestasi yang diinginkan, mahasiswa harus memperhatikan faktor-faktor yang dapat memengaruhi prestasi belajar. Menurut Tu'u (2004:78) faktor yang memengaruhi prestasi belajar adalah antara lain: kecerdasan. bakat, minat dan perhatian. motif, cara belajar, lingkungan keluarga, dan sekolah. Jalur masuk universitas negeri memang tidak termasuk dalam faktor-faktor yang tertulis di atas, namun bisa menjadi salah satu kriteria keberhasilan belajar karena merupakan input awal.

\section{METODE PENELITIAN}

Penelitian ini menggunakan metode deskriptif kuantitatif yaitu penelitian yang bertujuan menjelaskan fenomena yang ada dengan menggunakan angka-angka untuk mencandarkan karakteristik individu atau kelompok (Syamsudin \& Damiyanti: 2011). Subyek penelitian ini adalah mahasiswa Program Studi Pendidikan Bahasa Jepang dan Program Studi Sastra Cina, Fakultas Ilmu Budaya, Universitas Brawijaya.angkatan 2015. Penelitian ini menggunakan varibael bebas yaitu jalur masuk penerimaan mahasiswa serta variabel terikat yaitu prestasi belajar mahasiswa Program Studi Pendidikan Bahasa Jepang dan Program Studi Sastra Cina. Teknik pengumpulan data dengan cara dokumentasi Kartu Hasil Studi mahasiswa yang memuat prestasi belajar yang diakses melalui SIADO Universitas Brawijaya dan data jalur masuk mahasiswa yang diperoleh dari data akademik fakultas.

Populasi dalam penelitian ini adalah mahasiswa Prodi Pendidikan Bahasa Jepang dan Prodi Sastra Cina Fakultas Ilmu Budaya Universitas Brawijaya. Penelitian ini penulis mengambil sampel dengan menggunakan teknik purposive sampling. . Sampel yang digunakan dalam penelitian ini adalah 105 mahasiswa Prodi Pendidikan Bahasa Jepang dan Prodi Sastra Cina angkatan 2015. 
TABEL 2. DATA NILAI IPK MAHASISWA PENDIDIKAN JEPANG TAHUN 2015

\begin{tabular}{|c|c|c|c|}
\hline \multirow{2}{*}{ No } & \multicolumn{3}{|l|}{ Nilai IPK } \\
\hline & SBMPTN & SNMPTN & Mandiri/ SPMK \\
\hline 1 & 3,83 & 2,81 & 3,02 \\
\hline 2 & 3,64 & 3,06 & 3,29 \\
\hline 3 & 3,77 & 2,84 & 2,85 \\
\hline 4 & 2,96 & 2,72 & 3,35 \\
\hline 5 & 3,01 & 2,59 & 3,48 \\
\hline 6 & 3,37 & 2,65 & 2,77 \\
\hline 7 & 3,10 & 2,83 & 2,96 \\
\hline 8 & 3,36 & 3,91 & 2,67 \\
\hline 9 & 2,81 & 2,39 & 2,74 \\
\hline 10 & 3,66 & 2,71 & 2,36 \\
\hline 11 & 3,30 & 3,55 & 3,02 \\
\hline 12 & 3,52 & 3,47 & 2,62 \\
\hline 13 & 3,11 & 2,56 & \\
\hline 14 & 3,58 & 2,85 & \\
\hline 15 & 2,87 & 3,77 & \\
\hline 16 & 2,98 & 3,46 & \\
\hline 17 & 2,95 & 2,37 & \\
\hline 18 & 3,80 & 2,90 & \\
\hline 19 & 2,55 & 2,44 & \\
\hline 20 & 3,21 & 2,55 & \\
\hline 21 & 3,13 & 2,72 & \\
\hline 22 & 3,67 & & \\
\hline 23 & 3,88 & & \\
\hline $\mathrm{N}$ & 23 & 21 & 12 \\
\hline Rata-rata & 3,31 & 2,91 & 2,93 \\
\hline Standart Deviasi & 0,38 & 0,45 & 0,33 \\
\hline Minimum & 2,55 & 2,37 & 2,36 \\
\hline Maksimum & 3,88 & 3,91 & 3,48 \\
\hline
\end{tabular}

Tahapan penyajian data dalam penelitian ini adalah sebagai berikut; sebelum dilakukan analisis ragam One-way ANOVA terhadap data hasil penelitian terlebih dahulu dilakukan uji asumsi yang melandasi pengujian tersebut. Uji asumsi yang melandasi analisis ragam One-way ANOVA adalah uji normalitas data dan uji homogenitas ragam. Apabila salah satu asumsi yang melandasi pengujian analisis ragam One-way ANOVA tidak terpenuhi maka analisis ragam One-way ANOVA dapat digantikan dengan uji statistik non-parametrik Kruskal-Wallis. 


\section{HASIL DAN PEMBAHASAN}

Berdasarkan tabel 2 pada kelompok SBMPTN yang terdiri dari 23 mahasiswa diperoleh rata-rata nilai IPK sebesar 3,31 dengan standart deviasi sebesar 0,38. Nilai IPK minimum pada kelompok ini sebesar 2,55 dengan nilai IPK maksimum sebesar 3,88 . Pada kelompok SNMPTN yang terdiri dari 21 orang, diperoleh rata-rata nilai IPK sebesar 2,91 dengan standart deviasi sebesar 0,45. Nilai IPK minimum pada kelompok ini sebesar 2,37 dengan nilai IPK maksimum mencapai 3,91. Sedangkan pada kelompok Mandiri/ SPMK yang terdiri dari 12 orang, diperoleh rata-rata nilai IPK sebesar 2,93 dengan standart deviasi sebesar 0,33. Nilai IPK minimum pada kelompok ini sebesar 2,36 dengan nilai IPK maksimum sebesar 3,48. Sedangkan hasil perhitungan data mahasiswa Prodi sastra Cina adalah sebagai berikut: (Lihat Tabel 3)

Berdasarkan tabel di atas, pada kelompok SBMPTN yang terdiri dari 17 mahasiswa diperoleh rata-rata nilai IPK sebesar 3,38 dengan standart deviasi sebesar 0,31. Nilai IPK minimum pada kelompok ini sebesar 2,98 dengan nilai IPK maksimum sebesar 3,79. Pada kelompok SNMPTN yang terdiri dari 19 orang, diperoleh rata-rata nilai IPK sebesar 3,47 dengan standart deviasi sebesar 0,29. Nilai IPK minimum pada kelompok ini sebesar 2,93 dengan nilai IPK maksimum mencapai 3,87. Sedangkan pada kelompok Mandiri/ SPMK yang terdiri dari 13 orang, diperoleh rata-rata nilai IPK sebesar 3,37 dengan standart deviasi sebesar 0,28. Nilai IPK minimum pada kelompok ini sebesar 3,05 dengan nilai IPK maksimum sebesar 3,77.

\section{A. PENGUJIAN ASUMSI DATA}

Sebelum dilakukan analisis ragam One-way ANOVA terhadap data hasil penelitian terlebih dahulu dilakukan uji asumsi yang melandasi pengujian tersebut. Uji asumsi yang melandasi analisis ragam One-way ANOVA adalah uji normalitas data dan uji homogenitas ragam. Apabila salah satu asumsi yang melandasi pengujian analisis ragam One-way ANOVA tidak terpenuhi maka 
TABEL 3. DATA NILAI IPK PRODI SASTRA CINA

\begin{tabular}{llll}
\hline \multirow{4}{*}{ No } & \multicolumn{3}{l}{ Nilai IPK } \\
\cline { 2 - 4 } & SBMPTN & SNMPTN & Mandiri/ SMPK \\
\hline 1 & 3,71 & 3,48 & 3,60 \\
2 & 3,79 & 3,67 & 3,10 \\
3 & 3,08 & 3,80 & 3,13 \\
4 & 3,51 & 3,25 & 3,60 \\
5 & 3,10 & 3,87 & 3,05 \\
6 & 2,98 & 2,93 & 3,15 \\
7 & 3,79 & 3,14 & 3,57 \\
8 & 3,52 & 3,18 & 3,26 \\
9 & 3,19 & 3,83 & 3,77 \\
10 & 3,15 & 3,72 & 3,74 \\
11 & 3,09 & 3,58 & 3,15 \\
12 & 3,72 & 3,51 & 3,65 \\
13 & 3,16 & 3,77 & 3,07 \\
14 & 3,64 & 3,60 & \\
15 & 3,78 & 3,69 & \\
16 & 3,06 & 3,28 & \\
17 & 3,25 & 3,49 & \\
18 & & 3,08 & \\
19 & & 3,10 & 13 \\
\hline N & 17 & 19 & 3,37 \\
Rata-rata & 3,38 & 3,47 & 0,28 \\
Standart Deviasi & 0,31 & 0,29 & 3,05 \\
Minimum & 2,98 & 2,93 & 3,77 \\
Maksimum & 3,79 & 3,87 & \\
\hline & & & \\
\hline
\end{tabular}

analisis ragam One-way ANOVA dapat digantikan dengan uji statistik non-parametrik Kruskal-Wallis.

\section{- Uji Normalitas Data}

Pengujian normalitas data pada penelitian ini menggunakan uji Kolmogorov-Smirnov. Suatu data hasil penelitian dikatakan berdistribusi normal apabila nilai signifikan (p-value) hasil analisis lebih besar dari 0,05. Hasil uji normalitas data dapat dilihat pada tabel berikut ini. 
TABEL 4. HASIL UJI NORMALITAS DATA MAHASISWA PRODI PENDIDIKAN JEPANG

\begin{tabular}{lllll}
\hline \multirow{N}{*}{$\mathrm{N}$} & & SBMPTN & SNMPTN & SPMK \\
\cline { 3 - 5 } & & 23 & 21 & 12 \\
\hline Normal Parameters ${ }^{\mathrm{a}, \mathrm{b}}$ & Mean & 3,3070 & 2,9119 & 2,9275 \\
& Std. Deviation &, 37717 &, 45442 &, 32783 \\
Most Extreme Differences & Absolute &, 116 &, 225 &, 139 \\
& Positive &, 115 &, 225 &, 139 \\
& Negative &,- 116 &,- 124 &,- 116 \\
Kolmogorov-Smirnov Z & &, 555 & 1,030 &, 481 \\
Asymp. Sig. (2-tailed) & &, 918 &, 239 &, 975 \\
\hline
\end{tabular}

Berdasarkan tabel di atas terlihat bahwa nilai signifikansi hasil pengujian data nilai IPK pada masing-masing kelompok lebih besar dari 0,05 sehingga disimpulkan data nilai IPK berdistribusi normal. Sedangkan hasil uji normalitas data mahasiswa Prodi sastra Cina adalah sebagai berikut:

TABEL 5. HASIL UJI NORMALITAS PRODI SASTRA CINA

\begin{tabular}{lllll}
\hline $\mathrm{N}$ & & SBMPTN & SNMPTN & SPMK \\
& & 17 & 19 & 13 \\
\hline Normal Parameters ${ }^{\mathrm{a}, \mathrm{b}}$ & Mean & 3,3835 & 3,4721 & 3,3723 \\
& Std. Deviation &, 30555 &, 29141 &, 28178 \\
\multirow{3}{*}{ Most Extreme Differences } & Absolute &, 207 &, 142 &, 246 \\
& Positive &, 207 &, 114 &, 246 \\
& Negative &,- 152 &,- 142 &,- 220 \\
Kolmogorov-Smirnov Z & &, 855 &, 621 &, 889 \\
Asymp. Sig. (2-tailed) & &, 458 &, 836 &, 409 \\
\hline
\end{tabular}

Berdasarkan tabel di atas terlihat bahwa nilai signifikansi hasil pengujian data nilai IPK pada masing-masing kelompok lebih besar dari 0,05 sehingga disimpulkan data nilai IPK berdistribusi normal.

\section{- Uji Homogenitas Ragam}

Pengujian homogenitas ragam pada penelitian ini menggunakan uji Levene. Suatu kelompok data dikatakan memiliki ragam yang homogen apabila nilai signifikan ( $p$-value) 
hasil analisis lebih besar dari 0,05. Hasil uji homogenitas ragam data dapat dilihat pada tabel 3 berikut ini.

TABEL 6. HASIL UJ HOMOGENITAS RAGAM PRODI PENDIDIKAN JEPANG

\begin{tabular}{cccc}
\hline Levene Statistic & $\mathrm{df1}$ & $\mathrm{df2}$ & Sig. \\
\hline 0,753 & 2 & 53 & 0,476 \\
\hline
\end{tabular}

Berdasarkan tabel 6 terlihat bahwa data Nilai IPK pada 3 kelompok sampel memiliki ragam yang homogen karena nilai signifikansi hasil analisis menunjukkan lebih besar dari taraf nyata 0,05 . Sedangkan untuk data Uji Homogenitas Ragam mahasiswa Prodi Sastra Cina adalah sebagai berikut:

TABEL 7. HASIL UJ HOMOGENITAS RAGAM PRODI SASTRA CINA

\begin{tabular}{cccc}
\hline Levene Statistic & $\mathrm{df1}$ & $\mathrm{df2}$ & Sig. \\
\hline 0,422 & 2 & 46 & 0,658 \\
\hline
\end{tabular}

Berdasarkan tabel 7 terlihat bahwa data Nilai IPK pada 3 kelompok sampel memiliki ragam yang homogen karena nilai signifikansi hasil analisis menunjukkan lebih besar dari taraf nyata 0,05 .

Pengujian terhadap asumsi normalitas dan homogenitas ragam yang melandasi uji One-way ANOVA telah dilakukan dan didapatkan hasil bahwa data hasil pengamatan telah memenuhi kedua asumsi tersebut. Sehingga selanjutnya data hasil penelitian akan diuji menggunakan uji One-way ANOVA pada taraf nyata 5\%. Apabila hasil uji One-way ANOVA menunjukkan berbeda signifikan maka akan dilanjutkan dengan uji Tukey untuk mengetahui ada tidaknya perbedaan signifikan antar kelompok sampel. 


\section{B. UJI ONE-WAY ANOVA}

TABEL 8. HASIL ONE-WAY ANOVA PRODI PENDIDIKAN BAHASA JEPANG

\begin{tabular}{llllll}
\hline & $\begin{array}{c}\text { Sum of } \\
\text { Squares }\end{array}$ & df & Mean Square & F & Sig. \\
\hline Between Groups & 2,057 & 2 & 1,028 & 6,457 & 0,003 \\
Within Groups & 8,442 & 53 & 0,159 & & \\
Total & 10,499 & 55 & & & \\
\hline
\end{tabular}

Berdasarkan hasil analisis One-way ANVOA diperoleh nilai Fhitung sebesar 6,457 dengan nilai signifikansi sebesar 0,003. Nilai Ftabel pada derajat bebas 2 dan 53 serta taraf nyata 5\% adalah 3,172. Karena nilai Fhitung $>$ Ftabel atau nilai signifikansi $<0,05$ maka disimpulkan terdapat perbedaan yang signifikan rata-rata Nilai IPK antar kelompok sampel. Untuk mengetahui kelompok mana yang memiliki perbedaan signifikan dengan kelompok lainnya terhadap nilai IPK maka dilakukan uji lanjut Tukey. Berikut hasil analisisnya:

TABEL 9. HASIL UJI TUKEY PRODI PENDIDIKAN BAHASA JEPANG

\begin{tabular}{llll}
\hline Kelompok & $\mathrm{N}$ & \multicolumn{2}{l}{ Nilai rata-rata } \\
& & 1 & 2 \\
\hline SNMPTN & 21 & 2,91 & \\
Mandiri/ SMPK & 12 & 2,93 & \\
SBMPTN & 23 & & 3,31 \\
\hline
\end{tabular}

Berdasarkan uji tabel di atas, rata-rata nilai IPK terendah terdapat pada kelompok SNMPTN yaitu sebesar 2,91. Nilai ratarata ini tidak berbeda signifikan dengan rata-rata nilai IPK kelompok Mandiri/ SPMK karena hasil uji Tukey menunjukkan rata-rata kedua ini berada pada kolom yang sama. Sedangkan pada kelompok SBMPTN yang memiliki rata-rata IPK sebesar 3,31 berada pada kolom yang berbeda dengan kedua kelompok yang lain, artinya kelompok ini memiliki rata-rata IPK yang berbeda signifikan dengan kelompok SNMPTN dan Mandiri/ SMPK. 
TABEL 10. HASIL ONE-WAY ANOVA PRODI SASTRA CINA

\begin{tabular}{llllll}
\hline & $\begin{array}{l}\text { Sum of } \\
\text { Squares }\end{array}$ & df & $\begin{array}{l}\text { Mean } \\
\text { Square }\end{array}$ & F & Sig. \\
\hline Between Groups & 0,102 & 2 & 0,051 & 0,593 & 0,557 \\
Within Groups & 3,975 & 46 & 0,086 & & \\
Total & 4,078 & 48 & & & \\
\hline
\end{tabular}

Berdasarkan hasil analisis One-way ANVOA diperoleh nilai Fhitung sebesar 0,593 dengan nilai signifikansi sebesar 0,557. Nilai Ftabel pada derajat bebas 2 dan 46 serta taraf nyata 5\% adalah 3,200. Karena nilai Fhitung < Ftabel atau nilai signifikansi $>$ 0,05 maka disimpulkan tidak terdapat perbedaan yang signifikan rata-rata Nilai IPK antar kelompok sampel. Untuk mengetahui kelompok mana yang memiliki perbedaan signifikan dengan kelompok lainnya terhadap nilai IPK maka dilakukan uji lanjut Tukey. Berikut hasil analisisnya:

TABEL 11. HASIL UJ TUKEY

\begin{tabular}{ccc}
\hline Kelompok & $\mathrm{N}$ & $\begin{array}{c}\text { Nilai Rata-rata } \\
1\end{array}$ \\
\hline Mandiri/ SMPK & 13 & 3,37 \\
SBMPTN & 17 & 3,38 \\
SNMPTN & 19 & 3,47 \\
\hline
\end{tabular}

Berdasarkan uji tabel di atas, rata-rata nilai IPK terendah terdapat pada kelompok Mandiri/ SPMK yaitu sebesar 3,37. Sedangkan rata-rata nilai IPK tertinggi terdapat pada kelompok SNMPTN yaitu sebesar 3,47. Berdasarkan hasil uji Tukey menunjukkan bahwa ketiga kelompok yaitu Mandiri/ SPMK, SBMPTN dan SNMPTN terdapat pada kolom yang sama, artinya ketiga kelompok memiliki nilai rata-rata IPK yang tidak berbeda signifikan satu dengan yang lain.

Berdasarkan hasil analisis di atas diperoleh data prestasi belajar mahasiswa Prodi Pendidikan Jepang dan Prodi Sastra Cina angkatan 2015 berdasarkan jalur masuk mahasiswa yang memiliki nilai IPK tertinggi adalah yang diterima melalui SNMPTN dengan 
nilai IPK maksimum 3,91 dan 3,87. Kemudian jalur SBMPTN sebesar 3,88 dan nilai 3,79 sedangkan yang paling rendah adalah jalur mandiri sebesar 3,48 dan 3,77. Nilai rata-rata IPK mahasiswa Prodi Pendidikan Bahasa Jepang dari jalur SBMPTN dengan nilai 3.3 kemudian jalur mandiri 2,93 dan yang paling rendah adalah jalur SNMPTN 2,91. Mahasiswa Prodi Sastra Cina memiliki IPK rata-rata dari jalur SNMPTN dengan nilai 3,47 kemudian jalur SBMPTN 3,38 yang yang paling rendah adalah jalur mandiri 3,37 .

Berdasarkan uraian di atas menunjukkan bahwa mahasiswa Prodi Pendidikan bahasa Jepang yang diterima melalui jalur SBMPTN memunyai rata-rata nilai IPK tertinggi dibandingkan dari jalur mandiri dan jalur SNMPTN. Sedangkan rata-rata IPK mahasiswa Sastra Cina yang masuk melalui jalur SNMPTN masih menduduki tingkat tertinggi daripada jalur SBMPTN maupun jalur mandiri meskipun tidak berbeda secara signifikan. Hasil penelitian ini tidak sejalan dengan tujuan dari seleksi SNMPTN yang sangat diistimewakan selain diterima tanpa tes, mahasiswa ini juga berpeluang memeroleh beasiswa Bidik Misi. Siswa yang diterima melalui jalur SNMPTN memang memunyai prestasi di masing-masing sekolah yang standarnya tidak sama, sehingga siswa yang berprestasi di setiap sekolah belum tentu memiliki prestasi yang sama jika dibandingkan siswa dari sekolah lain. Bibit-bibit unggul di sekolah masing-masing diharapkan juga akan tetap menjadi bibit-bibit unggul di Perguruang Tinggi ini namun pada kenyataannya hasil belajar yang diperoleh tidak berbeda secara signifikan dengan mahasiswa yang masuk dengan jalur yang lain. Sehingga dapat disimpulkan bahwa berbagai kemudahan yang diterima oleh mahasiswa SNMPTN belum mampu memberikan kontribusi dalam meningkatkan prestasi belajar mahasiswa di Perguruan Tingga Negeri.

Mahasiswa yang masuk dari jalur SBMPTN memunyai nilai rata-rata tinggi. Ini dapat dipahami karena mahasiswa yang diterima dari jalur SBMPTN adalah mahasiswa yang lolos seleksi nasional melalui jalur tulis dengan persaingan yang sangat ketat 
dan lebih mengutamakan intelejensi, sehingga tingkat intelejensia dapat berpengaruh terhadap prestasi belajar di Perguruang Tinggi.

Dari hasil penelitian ini juga dapat diketahui bahawa pada Prodi Sastra Cina prestasi belajar mahasiswa jalur mandiri memiliki IPK rata-rata yang tidak berbeda jauh dengan jalur SNMPTN dan SBMPTN dan yang diluar dugaan adalah pada Prodi Pendidikan Jepang mahasiswa yang masuk dari jalur mandiri berada dibawah SBMPTN mengalahkan nilai IPK ratarata mahasiswa jalur SNMPTN. Sehingga dapat disimpulkan

bahwa jalur masuk perguruan tinggi masih belum dapat menjamin prestasi belajar mahasiswa di perguruan tinggi. Minat dan perhatian akan menghasilkan motivasi belajar dan keinginan berhasil dalam diri mahasiswa yang merupakan modal utama untuk meraih prestasi setinggi-tingginya di perguruan tinggi sejalan dengan pernyataan Tu'u (2004:78), yaitu salah satu faktor yang memengaruhi prestasi belajar adalah faktor minat dan perhatian. Minat dan perhatian yang tinggi pada mata pelajaran akan memberi dampak yang baik bagi prestasi belajar siswa.

\section{SIMPULAN}

Hasil penelitian ini menunjukkan bahwa nilai rata-rata IPK mahasiswa Prodi Pendidikan Bahasa Jepang yang masuk dari jalur SBMPTN adalah 3.3 disusul dengan jalur mandiri 2,93 dan jalur SNMPTN 2,91. Mahasiswa Prodi Sastra Cina memiliki IPK ratarata dari jalur SNMPTN dengan nilai 3,47 kemudian jalur SBMPTN 3,38 yang yang paling rendah adalah jalur mandiri 3,37.

Dari hasilyang tersebut di atas diketahui bahwa pada Prodi Sastra Cina prestasi belajar mahasiswa jalur mandiri memiliki IPK rata-rata yang tidak berbeda jauh dengan jalur SNMPTN dan SBMPTN dan yang diluar dugaan adalah pada Prodi Pendidikan Jepang, mahasiswa yang masuk dari jalur mandiri berada dibawah SBMPTN mengalahkan nilai IPK rata-rata mahasiswa jalur SNMPTN. Sehingga dapat disimpulkan bahwa jalur masuk perguruan tinggi masih belum dapat menjamin prestasi belajar mahasiswa di perguruan tinggi. Minat dan 
perhatian akan menghasilkan motivasi belajar dan keinginan berhasil dalam diri mahasiswa yang akan merupakan modal utama untuk meraih prestasi setinggi-tingginya di perguruan tinggi

Berdasarkan hasil penelitian ini, peneliti memberikan saran sebagai berikut:

1. Perlu adanya pengkajian kembali mengenai sistem penerimaan mahasiswa baru, bahwasanya tidak selalu mahasiswa yang diterima melalui jalur SNMPTN pada masa perkuliahan dapat mempertahankan prestasi yang telah diraih pada masa di sekolah menengah. Dosen pembimbing akademik perlu kiranya berperan untuk mencari penyebab terjadinya penurunan prestasi dari mahasiswa jalur SNMPTN.

2. Untuk penelitian selanjutnya diharapkan mencari faktorfaktor penyebab penurunan prestasi dari mahasiswa jalur SNMPTN sehingga dapat menjadi rujukan untuk sistem penerimaan mahasiswa baru di Perguruan Tinggi Negeri.

\section{DAFTAR PUSTAKA}

Arikunto, Prof. Dr. Suharsimi. 2010. Prosedur Penelitian Suatu Pendekatan Praktek (Revisi VI). Jakarta: PT. Rineka Cipta. Bloor, Thomas and Bloor .

Hamalik Oemar. 2001.Proses Belajar Mengajar. Bandung: Bumi Aksara

Herman Hidayat \& Kartono Sukarto. 2010. Pengaruh Minat Belajar Siswa terhadap Prestasi

Belajar Mata Diklat PDTM. Jurnal Pendidikan Teknik Mesin. Vol. 10 No. 1, Juni 2010.

Versi Elektronik. Diakses dari http: www. journal.unness.ac.id

Kemenristek dikti No.2 tahun 2015

M Nur Ghufron \& Rini Risnawati 2012. Gaya Belajar. Yogyakarta: Pustaka Pelajar. Moleong, L.J.2010. Metodologi Penelitian Kualitatif. Bandung: remaja Rosda Karya. Poerwodarminto. 1991. Kamus Umum Bahasa Indonesia. Jakarta: Bina Ilmu Suryabrta, Sumadi. 2005. Psikologi Pendidikan. Jakarta : Raja Grafindo Persada Syaiful Bahri Djamarah. 1994. Prestasi Belajar dan Kompetensi Guru. Surabaya: Usaha Nasional

Syamsuddin, dkk. 2011. Metode Penelitian Pendidikan Bahasa. Bandung: PT. Remaja Rosdakarya.

Tu'u, Tulus. 2004. Peran Disiplin pada Prilaku dan Prestasi Siswa. Jakarta: PT Grasindo. 